\title{
Nociceptin/orphanin FQ prevents the antinociceptive action of paracetamol on the rat hot plate test
}

\author{
Maurizio Sandrini ${ }^{\mathrm{a}, *}$, Giovanni Vitale ${ }^{\mathrm{a}}$, Luigi Alberto Pini ${ }^{\mathrm{b}}$, Giuseppe Lopetuso ${ }^{\mathrm{c}}$, \\ Patrizia Romualdi ${ }^{\mathrm{c}}$, Sanzio Candeletti ${ }^{\mathrm{c}}$ \\ ${ }^{a}$ Department of Biomedical Sciences, Section of Pharmacology, Italy \\ ${ }^{\mathrm{b}}$ Clinical Pharmacology Unit, University of Modena and Reggio Emilia, 41100 Modena, Italy \\ ${ }^{\mathrm{c}}$ Department of Pharmacology, University of Bologna, 40126 Bologna, Italy
}

Received 9 November 2004; accepted 15 November 2004

Available online 15 December 2004

\begin{abstract}
Nociceptin/orphanin FQ (N/OFQ) is involved in many behavioural patterns; in particular, it exerts a modulating effect on nociception. Like other proposed antiopiates, nociceptin/orphanin FQ has been shown to have analgesic, hyperalgesic as well as antianalgesic properties. Among the various effects proposed on nociceptive sensitivity at supraspinal level, the antagonistic activity toward morphine analgesia seems to be of interest. Therefore, we decided to investigate whether nociceptin/orphanin FQ and $\left[\mathrm{Arg}^{14}\right.$, Lys ${ }^{15}$ ] nociceptin/orphanin FQ (R-K, a nociceptin analogue) can have the same effect on the analgesia produced by nonopioid analgesics. In this study, we examined the antianalgesic effect of nociceptin/orphanin FQ and its analogue R-K on paracetamol-induced analgesia and evaluated by means of the hot plate test in rats. Nociceptin/orphanin FQ was intracerebroventricularly administered, and, after $5 \mathrm{~min}$, a dose of $400 \mathrm{mg} / \mathrm{kg}$ paracetamol was injected intraperitoneally, $30 \mathrm{~min}$ before the hot plate test. Nociceptin/orphanin FQ and R-K showed a dose-dependent antagonism on the antinociceptive effect of paracetamol, and the activity of both drugs was significantly reduced by the antagonist $\left[\mathrm{Nphe}^{1}\right] \mathrm{Arg}^{14}$, Lys ${ }^{15}-\mathrm{N} /$ OFQ- $\mathrm{NH}_{2}$ (UFP-101). These data indicate that nociceptin/orphanin FQ and R-K have an antianalgesic effect on the analgesia produced by a nonopioid analgesic drug, like paracetamol, that seems to develop within the brain.
\end{abstract}

(C) 2004 Elsevier B.V. All rights reserved.

Keywords: N/OFQ (nociceptin/orphanin FQ); R-K, paracetamol; UFP-101; Analgesia; Hot plate test

\section{Introduction}

Nociceptin/orphanin has been identified as a potent endogenous agonist of ORL1 receptors currently named as NOP receptor (Cox et al., 2000). This 17 -amino acid peptide shares a structure related to the peptide dynorphin A 1-17 (Julius, 1995). The NOP receptor was identified as a Gprotein-coupled receptor that mediates the inhibition of adenyl cyclase (Meunier et al., 1995), the reduction of calcium channel conductance (Connor et al., 1996) and the activation of potassium channels (Vaugham and Christie,

\footnotetext{
* Corresponding author. Tel.: +39 59 2055385; fax: +39 592055376

E-mail address: sandrini.maurizio@unimore.it (M. Sandrini).
}

1996). NOP receptor signalling is involved in several spinal and supraspinal actions, including opiate tolerance, dependence/withdrawal, adaptive response to anxiety and stress, reward, memory and pain (for a review, see Meis, 2003). The action on pain modulation seems to differ at spinal and supraspinal levels, creating in turn hyperalgesia, analgesia or antianalgesia, although evidence of the reported phenomena is not equally robust (Mogil and Pasternak, 2001). The supraspinal hyperalgesic action of nociceptin/orphanin FQ (N/OFQ) is transient compared with the antianalgesic action, the former lasting only 15-30 min and the latter being long-lasting (Candeletti and Ferri, 2000). Moreover, a functional antiopioid activity of nociceptin/orphanin FQ has been described (Mogil et al., 1996); when intracerebroventricularly (i.c.v.) injected, nociceptin/orphanin FQ can 
reverse or prevent analgesia from drugs acting on supraspinal $\mu$-opioid receptors, including morphine (Lufty et al., 1999) and $\delta$ - and $\kappa$-opioid agonists (Wang et al., 1999; Zhu et al., 1998). Finally, it has been shown that nociceptin/ orphanin FQ inhibits the neurotransmitter release in several nuclei within the central nervous system (CNS) in vivo and in vitro; in particular, it modulates 5-hydroxytryptamine (5HT) and noradrenaline efflux in synaptosomal preparation, chiefly in the cerebral cortex (Schlicker and Morari, 2000; Marti et al., 2003).

Many reports indicate that paracetamol exerts its antinociceptive activity by acting within the CNS, both at spinal and supraspinal levels, as well as peripherally (McCormack, 1994; Björkman, 1995). It has been suggested that a number of neurotransmitter systems may be involved in the central analgesic activity of paracetamol. In particular, the 5-HT pathways seem to play a pivotal role in the way this drug behaves (Pellissier et al., 1995; Pini et al., 1996). In our previous work, we demonstrated the importance of the central serotonergic system in the antinociceptive effect of paracetamol, matching an increase in serotonin levels and a decrease in the number of $5-\mathrm{HT}_{2}$ receptors in the cerebral cortex of the rat (Pini et al., 1996). On the basis of the above results, we decided to investigate the possible antagonistic effect of nociceptin/orphanin FQ and its analogue [ $\operatorname{Arg}^{14}$, Lys $^{15}$ ] nociceptin/orphanin FQ (R-K) on paracetamolinduced antinociception in the hot plate test in the rat to establish whether a pretreatment with $\left[\mathrm{Nphe}^{1}\right] \mathrm{Arg}^{14}, \mathrm{Lys}^{15}$ N/OFQ- $\mathrm{NH}_{2}$ (UFP-101, a specific NOP receptor antagonist, Calò et al., 2002) could revert the action of the two peptides on paracetamol activity.

\section{Methods}

\subsection{Animals and surgery}

Male Wistar rats weighing $180-200 \mathrm{~g}$ were housed in Plexiglas ${ }^{\circledR}$ cages in groups of three-four in controlled conditions (free access to food and water; 12-h dark/light cycle; temperature, $22 \pm 1{ }^{\circ} \mathrm{C}$; humidity, $60 \%$ ). The ethical guidelines for investigation of experimental pain in conscious animals were followed, and procedures were carried out according EEC ethical regulations for animal research (EEC Council 86/609; D.Lgs. 27/01/1992, No. 116).

The rats were randomly divided into groups of eight animals each. For i.c.v. administrations, stainless-steel guide cannulae (23 ga; Plastic One, Roanoke, VA, USA) were stereotaxically implanted in the right lateral ventricle to a depth of $0.5 \mathrm{~mm}$ above the ventricle (in millimeters from the bregma: $\mathrm{AP}=-0.8 ; \mathrm{L}=1.4 ; \mathrm{V}=3.25$ ) (Paxinos and Watson, 1997) under ketamine plus xylazine anesthesia $(115+2 \mathrm{mg} /$ kg i.p.; Farmaceutici Gellini, Aprilia, Italy and Bayer, Milan, Italy, respectively) and fixed in place with acrylic dental cement and one skull screw. A removable plug was kept in place except during the drug injections. After 5-7 days of recovery, the animal were subjected to an unheated plate test, and animal with alterations of gross behaviour were discarded. All i.c.v. injections were in a volume of $5 \mu$. After the end of the experiment, rats were i.c.v. injected with $5 \mu \mathrm{l}$ of dye (Evans blue) and sacrificed under anesthesia. The correct placement of the cannulae was ascertained by inspection of dye diffusion in the right lateral ventricle.

\subsection{Treatment}

Nociceptin/orphanin FQ, at the doses of 1,5 and 10 nmol, R-K, at the doses of $0.1,0.2,0.5$ and $2 \mathrm{nmol}$, or saline were intracerebroventricularly (i.c.v.) injected by means of an indwelling cannula (1 mm longer than the guide cannula) $5 \mathrm{~min}$ before paracetamol $(400 \mathrm{mg} / \mathrm{kg}$ i.p.; dissolved in vehicle, which consisted of $12.5 \%$ of 1,2-propanediol in sterile saline) or vehicle, and the animals were subjected to the hot plate test $30 \mathrm{~min}$ later. This dose of paracetamol had proved effective in dose-response experiments under identical experimental conditions (Pini et al., 1996). Other groups of rats were administered with UFP-101 (10 and 20 nmol) $5 \mathrm{~min}$ before nociceptin/orphanin FQ or R-K plus paracetamol, or paracetamol alone, according to the above experimental schedule.

\subsection{Hot plate test}

The hot plate consisted of an electrically heated surface (Socrel DS-35, Ugo Basile, Comerio, VA, Italy) kept at a constant temperature of $54 \pm 0.4{ }^{\circ} \mathrm{C}$. The latencies for pawlicking or jumping were recorded for each animal. The analgesic efficacy of the drug was evaluated as a percentage of the maximum possible effect (\%MPE) according to the formula $(\mathrm{TL}-\mathrm{BL}) /(45-\mathrm{BL}) \times 100$, where TL-test latency, BL-baseline latency, 45-cut-off time in seconds.

\subsection{Motor activity}

Spontaneous coordinate activity was measured in a soundproof room by means of an activity analyser equipped with IR beam-array cages (Ugo Basile). The number of horizontal movements was recorded $30 \mathrm{~min}$ after the last treatment in rats receiving nociceptin/orphanin FQ (10 nmol) alone, R-K (0.5 nmol) alone, nociceptin/orphanin FQ or R-K in combination with paracetamol $(400 \mathrm{mg} / \mathrm{kg})$, saline, and those pretreated with UFP-101 $(20 \mathrm{nmol})$. The number of impulses was continuously recorded for $5 \mathrm{~min}$.

\subsection{Drugs}

Paracetamol was purchased from Sigma-Aldrich (Milan, Italy); the heptadecapeptide nociceptin/orphanin FQ (PheGly $^{2}$-Phe-Thr-Gly-Ala-Arg-Lys-Ser-Ala-Arg-Lys-LeuAla-Asn-Gln) from Bakem-UK, Merseyside, UK; [ $\mathrm{Arg}^{14}$, $\mathrm{Lys}^{15}$ ] nociceptin/orphanin FQ (R-K) and $\left[\mathrm{Nphe}^{1}\right] \mathrm{Arg}^{14}$, Lys $^{15}-\mathrm{N} / \mathrm{OFQ}-\mathrm{NH}_{2}$ (UFP-101) synthesised as described 
(Rizzi et al., 2002) were kindly supplied by Dr. R. Guerrini and Dr. G. Calò (University of Ferrara, Italy).

\subsection{Statistical analysis}

The data obtained from the hot plate and motor activity experiments were expressed as means \pm S.E.M. A two-way analysis of variance (ANOVA) was used to analyse the effect of nociceptin/orphanin FQ or R-K pretreatment, paracetamol treatment and their interaction followed by $2 \times 2$ factorial analysis by means of orthogonal comparisons.

A three-way ANOVA using the program package SPSS 11.0 (SPSS Chicago, IL, USA) was performed to examine the effect of paracetamol, nociceptin/orphanin FQ, R-K, UFP-101 treatment and their interaction in the hot plate test and in motor activity analysis. The Bonferroni post hoc test was used for both the two-way and three-way ANOVA when the effects of nociceptin/orphanin FQ, R-K, UFP-101 and paracetamol have been separately evaluated. The level of significance was set at 0.05 .

\section{Results}

Paracetamol (400 $\mathrm{mg} / \mathrm{kg}$ ) significantly increased the $\% \mathrm{MPE}$ values in the hot plate test, as expected. Nociceptin/orphanin FQ did not change the \%MPE values at any dose used (Fig. 1). At the doses of 1 and $5 \mathrm{nmol}$, nociceptin/ orphanin FQ reduced the antinociceptive effect of paracetamol at different degrees. Nociceptin/orphanin FQ (1 nmol) plus paracetamol values were significantly different from control values and did not differ from paracetamol (alone) values. The interaction test showed no significance. The dose of $5 \mathrm{nmol}$ had an antagonistic effect on the paracetamol activity, the interaction test showing significance. The highest dose used of nociceptin/orphanin FQ completely abolished the effect of paracetamol. The \%MPE values were no different from those of controls, with the interaction test showing high significance.

The effect of nociceptin/orphanin FQ was dose-dependent since the increase in \%MPE values induced by paracetamol was completely blocked by the highest dose of the neuropeptide, while the effect of paracetamol was reduced by the two lower doses $(-30.1 \%$ and $-56,7 \%$ for 1 and $5 \mathrm{nmol}$, respectively).

Then, we investigated whether a pretreatment with UFP$101(10$ and $20 \mathrm{nmol})$ was able to prevent the antagonistic effect of nociceptin/orphanin FQ on paracetamol-induced antinociception, evaluating data by means of the three-way ANOVA.

UFP-101 was not able to modify the basal nociception (\%MPE: $5.45 \pm 2.37$ and $5.67 \pm 2.83$ for 10 and $20 \mathrm{nmol}$, respectively, vs. $1.24 \pm 0.62$ for controls; $P>0.05$, not shown). Furthermore, paracetamol-induced nociception remained unchanged by UFP-101 at any dose used (Fig. 1 , see note). The latter result was confirmed by the lack of

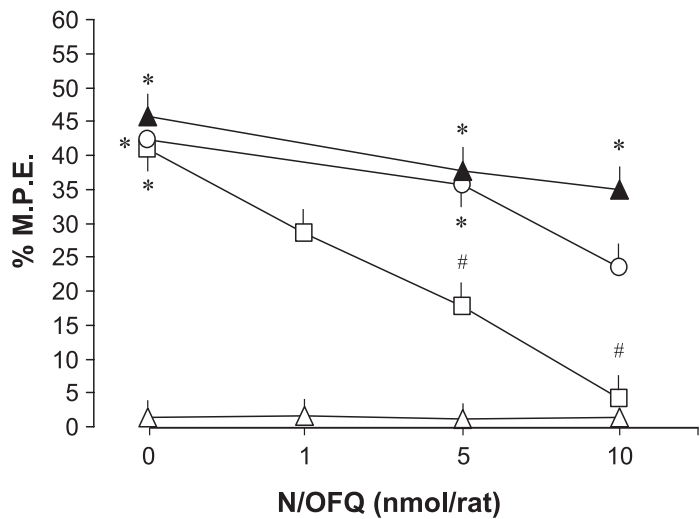

$$
\begin{array}{ll}
- \text { SAL + N/OFQ + VEH } & - \text { SAL + N/OFQ + PARA } \\
-\square-\text { UFP } 10+\text { N/OFQ + PARA } & - \text { UFP } 20+\text { N/OFQ + PARA }
\end{array}
$$

Fig. 1. Effect of nociceptin/orphanin FQ (N/OFQ, 1, 5 and $10 \mathrm{nmol} / \mathrm{rat}$, i.c.v.) on the antinociceptive action of paracetamol (PARA, $400 \mathrm{mg} / \mathrm{kg}$, i.p.) in the hot plate test: two-way ANOVA, $F(7-56)=4.97, P<0.01$; influence of UFP-101 (UFP, 10 and $20 \mathrm{nmol} /$ rat, i.c.v.) thereon: three-way ANOVA, $F(13-104)=3.36, P<0.01$. PARA was administered $5 \mathrm{~min}$ after $\mathrm{N} / \mathrm{OFQ}$, and the rats were tested $30 \mathrm{~min}$ later. Pretreatment experiments were performed injecting UFP-101, $5 \mathrm{~min}$ before N/OFQ; PARA was administered $5 \mathrm{~min}$ later. Each point represents the percentage of the maximum possible effect (\%MPE); values were expressed as mean \pm S.E.M. of eight rats for each group. Controls-saline (SAL) $+\mathrm{SAL}+$ vehicle (VEH; consisting of $12.5 \%$ of 1,2-propanediol in sterile saline)-treated rats. Data of the two experiments have been gathered in this figure to sum them up. ${ }^{*} P<0.05$ vs. control values; ${ }^{\#} P<0.05$ vs. SAL+SAL+PARA values (ANOVA followed by Bonferroni test). Note: the effect of UFP-101 pretreatment on paracetamol-induced antinociception is shown by the left end points of the lines corresponding to UFP 10 (or UFP 20)+N/OFQ+PARA, where the dose of $\mathrm{N} / \mathrm{OFQ}$ is equal to 0 .

interaction for UFP- $101 \times$ paracetamol treatment. ANOVA showed no significant main effect for paracetamol treatment, nociceptin/orphanin FQ (10 nmol) injection and UFP-101 (10 and $20 \mathrm{nmol})$ pretreatment. A significant UFP- $101 \times$ nociceptin/orphanin FQ treatment interaction was observed for both the doses of UFP-101 used, $F(1-$ $104)=5.38, P<0.05$ and $F(1-104)=7.43, P<0.01$, respectively. Furthermore, the UFP-101 $\times$ nociceptin/orphanin $\mathrm{FQ} \times$ paracetamol treatment interaction showed significance, $F(1-104)=6,74, P<0.05$ and $F(1-104)=7.98$, $P<0.01$, for 10 and $20 \mathrm{nmol}$ UFP-101, respectively.

A more detailed analysis using the Bonferroni test indicated that, at the dose of $10 \mathrm{nmol}$, UFP-101 partially reverted while, at the dose of $20 \mathrm{nmol}$, significantly prevented the antagonistic effect of the dose of $10 \mathrm{nmol}$ nociceptin/orphanin FQ on paracetamol-induced antinociception in the hot plate test $(-42.1 \%)$ (Fig. 1).

The effect of nociceptin/orphanin FQ analogue, $\left[\mathrm{Arg}^{14}\right.$, Lys $^{15}$ ] nociceptin/orphanin FQ (R-K), was then compared with the parent compound. R-K, given alone, slightly but not significantly increased the \%MPE values with respect to the controls only at the higher doses $(0.5$ and $2 \mathrm{nmol})$. R-K showed an effect similar to that of nociceptin/orphanin FQ on paracetamol-induced analgesia, but it differed in potency (Fig. 2). At the doses of 0.5 and $2 \mathrm{nmol}$, R-K completely 


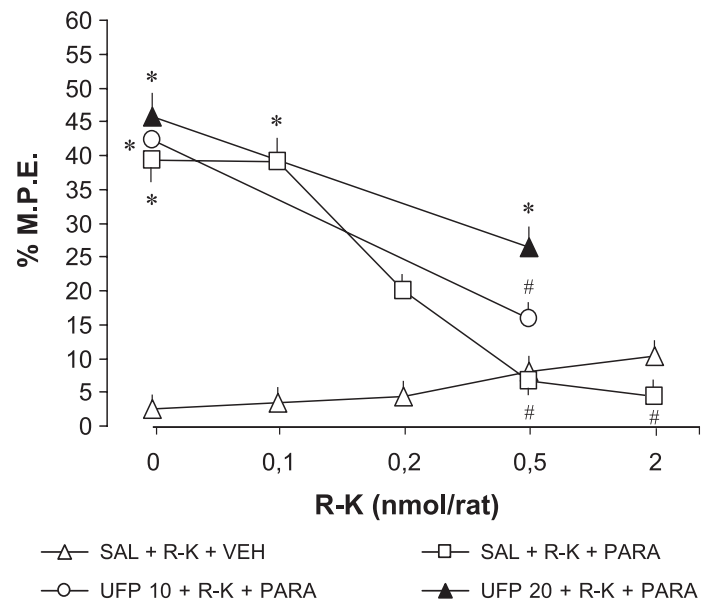

Fig. 2. Effect of $\mathrm{R}-\mathrm{K}(0.1,0.2,0.5$ and $2 \mathrm{nmol} / \mathrm{rat}$, i.c.v. $)$ on the antinociceptive action of paracetamol (PARA, $400 \mathrm{mg} / \mathrm{kg}$, i.p.) in the hot plate test: two-way ANOVA, $F(9-72)=3.23, P<0.01$; influence of UFP-101 (UFP, 10 and $20 \mathrm{nmol} / \mathrm{rat}$, i.c.v.) thereon: three-way ANOVA, $F(9-$ $72)=3.75, P<0.01$. PARA was administered $5 \mathrm{~min}$ after R-K, and the rats were tested $30 \mathrm{~min}$ later. Pretreatment experiments were performed injecting UFP-101, $5 \mathrm{~min}$ before R-K; PARA was administered $5 \mathrm{~min}$ later. Each point represents the percentage of the maximum possible effect $(\% \mathrm{MPE})$; values were expressed as mean \pm S.E.M. of eight rats for each group. Controls-saline (SAL)+SAL+vehicle (VEH; consisting in $12.5 \%$ of 1,2-propanediol in sterile saline)-treated rats. Data of the two experiments have been gathered in this figure to sum them up. ${ }^{*} P<0.05$ vs. control values; ${ }^{\#} P<0.05$ vs. SAL+SAL+PARA values (ANOVA followed by Bonferroni test). Note: the effect of UFP-101 pretreatment on paracetamol-induced antinociception is shown by the left end points of the lines corresponding to UFP 10 (or UFP 20)+R-K+PARA, where the dose of R-K is equal to 0 .

prevented the effect of paracetamol, while the lowest dose used $(0.1 \mathrm{nmol})$ was ineffective. The dose of $0.2 \mathrm{nmol}$ had an intermediate effect since it decreased the \%MPE values by $-48.5 \%$ towards paracetamol values. The interaction test showed significance for the three higher doses, indicating that, even in the case of R-K, the antagonistic effect was dosedependent. To analyse the effect of the pretreatment with UFP-101 on the R-K activity, we utilized the three-way ANOVA. No significant main effect was found for paracetamol treatment, R-K (0.5 nmol) injection and UFP-101

Table 1

Influence of nociceptin/orphanin FQ (N/OFQ, 10 nmol/rat, i.c.v.), UFP-101 (UFP, $20 \mathrm{nmol} / \mathrm{rat}$, i.c.v.) and/or paracetamol (PARA, $400 \mathrm{mg} / \mathrm{kg}$, i.p.) on motor activity in rats

\begin{tabular}{ll}
\hline Treatment & $\mathrm{N}^{\circ}$ of movements \\
\hline Controls & $150.38 \pm 51.48$ \\
SAL+N/OFQ 10+VEH & $134.81 \pm 28.43$ \\
UFP 20+SAL+VEH & $177.14 \pm 27.76$ \\
SAL+SAL+PARA & $148.34 \pm 25.92$ \\
UFP 20+SAL+PARA & $153.27 \pm 21.81$ \\
SAL+N/OFQ 10+PARA & $130.32 \pm 27.56$ \\
UFP 20+N/OFQ 10+PARA & $158.42 \pm 60.52$ \\
\hline
\end{tabular}

The analysis was performed $30 \mathrm{~min}$ after the last treatment. The number of horizontal movements was recorded continuously for $5 \mathrm{~min}$ and expressed as mean \pm S.E.M. of eight rats. The three-way ANOVA showed no significance: $F(6-49)=0.17, P=0.98$.
Table 2

Influence of R-K (0.5 nmol/rat, i.c.v.), UFP-101 (UFP, $20 \mathrm{nmol} /$ rat, i.c.v.) and/or paracetamol (PARA, $400 \mathrm{mg} / \mathrm{kg}$, i.p.) on motor activity in rats

\begin{tabular}{ll}
\hline Treatment & $\mathrm{N}^{\circ}$ of movements \\
\hline Controls & $142.75 \pm 62.93$ \\
SAL+R-K 0.5+VEH & $121.27 \pm 30.98$ \\
UFP-101 20+SAL+VEH & $169.23 \pm 29.11$ \\
SAL+SAL+PARA & $137.34 \pm 24.38$ \\
UFP 20+SAL+PARA & $153.27 \pm 21.81$ \\
SAL+R-K 0.5+PARA & $120.28 \pm 29.76$ \\
UFP 20+R-K 0.5+PARA & $144.22 \pm 30.12$ \\
\hline
\end{tabular}

The analysis was performed $30 \mathrm{~min}$ after the last treatment. The number of horizontal movements was recorded continuously for $5 \mathrm{~min}$ and expressed as mean \pm S.E.M. of eight rats. The three-way ANOVA showed no significance: $F(6-49)=0.24, P=0.96$.

(10 and $20 \mathrm{nmol})$ pretreatment. A significant interaction was found for UFP-101 $(20 \mathrm{nmol}) \times \mathrm{R}-\mathrm{K}, F(1-72)=4.56$, $P<0.05$, but no interaction was detected for the dose of $10 \mathrm{nmol}$ of UFP-101. UFP- $101 \times \mathrm{R}-\mathrm{K} \times$ paracetamol treatment showed significant interaction using the dose of 20 nmol UFP-101, $F(1-72)=4.12, P<0.05$, while the interaction was not present at the lower dose. As for nociceptin/orphanin FQ, no significant interaction was found for UFP-101 $\times$ paracetamol treatment at any dose used (Fig. 2, see note). The Bonferroni analysis demonstrated that UFP101 , at doses of 10 and $20 \mathrm{nmol}$, partially prevented the action of R-K ( $0.5 \mathrm{nmol})$ on paracetamol: only the highest dose had an antagonistic effect, and the \%MPE values were not significantly different from those of paracetamol alone, although they were different from those of controls. On the other hand, UFP-101 (10 nmol)+R-K+paracetamol values differed from those of paracetamol alone but not from control values (Fig. 2).

Nociceptin/orphanin FQ (10 n mol) and R-K (0.5 nmol) slightly decreased the motor activity $30 \mathrm{~min}$ after the final treatment, while paracetamol had no effect on locomotion and did not modify the effect of either nociceptin/orphanin FQ or R-K. Finally, UFP-101 (20 nmol) slightly increased the number of movements $40 \mathrm{~min}$ thereafter but had no effect on paracetamol. None of the effect reached significance (Tables 1 and 2).

\section{Discussion}

In the present study, we have demonstrated that nociceptin/orphanin FQ and its analogue R-K are able to antagonize in a dose-dependent manner the antinociceptive effect of paracetamol in the hot plate test. Previously, several authors reported that nociceptin/orphanin FQ was able to prevent the morphine-induced analgesia after i.c.v. injection, showing opiate-modulating properties (Mogil et al., 1996; Lufty et al., 1999; Harrison and Grandy, 2000). Little or no information is available about the effect of nociceptin/orphanin FQ and its analogues on the antinociceptive activity of nonopioid analgesics. The activity of 
analgesics may be dependent upon the antinociceptive test assay used to measure effect at peripheral, spinal and supraspinal levels. It has already been demonstrated that i.c.v. injected nociceptin/orphanin FQ elicits an antianalgesic effect in thermal and electrical assays (Mogil and Pasternak, 2001). The hot plate, heated to a constant temperature, produces two behavioural components that can be measured in term of reaction times, namely, licking and jumping; both are considered to be supraspinally integrated responses (Le Bars et al., 2001). This prompted us to use this test in our work, and our data confirm the relevance of the central component of the mechanism of action of paracetamol, suggesting that the interaction between nociceptin/orphanin FQ and paracetamol can occur within the brain.

Many data indicate that locomotion may influence nociception, but the changes have not always been well elucidated (Le Bars et al., 2001). However, we evaluated motility after treatment with the drugs used, both alone or in combination.

The antagonistic effect of nociceptin/orphanin FQ on paracetamol-induced antinociception described in this work does not seem to depend on the nociceptin/orphanin FQinduced decrease in motor activity (Devine et al., 1996) since a decrease in locomotion could potentially prolong the hot plate reaction times and so apparently increase the antinociceptive effect of paracetamol, while nociceptin/ orphanin FQ showed the opposite effect.

The nociceptin/orphanin FQ analogue, R-K, showed an antagonistic effect on paracetamol antinociception at doses about 20 times lower than those of nociceptin/orphanin FQ, indicating that the potency of nociceptin/orphanin FQ can be increased by little changes of the amino acid sequence.

On the basis of some literature data, we hypothesize a main role for serotonin in the antagonistic effect of nociceptin/orphanin FQ towards paracetamol antinociception. In fact, the antinociceptive effect of paracetamol is mediated by serotonin, both at spinal (Pelissier et al., 1996; Courade et al., 2001) and supraspinal levels (Pini et al., 1997). Secondly, in vitro studies showed that paracetamol enhanced the $\mathrm{K}^{+}$-evoked overflow of $\left[{ }^{3} \mathrm{H}\right]-5$-HT, thus indicating that paracetamol affects central serotonergic neurotransmission (Courade et al., 2001). On the other hand, recent data described a modulation of $\left[{ }^{3} \mathrm{H}\right]-5-\mathrm{HT}$ release by nociceptin/orphanin FQ in synaptosomes of the rat cortex (Sbrenna et al., 2000; Marti et al., 2003). Hence, a relationship between the two results could occur, and it could explain the antagonism exerted by nociceptin/orphanin FQ on the antinociceptive effect of paracetamol.

Nociceptin/orphanin FQ as well as R-K actions take place at their (NOP) receptor level since they were affected by a pretreatment with UFP-101 that partially but significantly prevented the antagonistic effect of both nociceptin/orphanin FQ and R-K on the antinociceptive effect of paracetamol in our experimental conditions. UFP-101 is a competitive antagonist of the NOP receptor and is able to antagonize many of the effects induced by nociceptin/orphanin FQ in vivo, including its analgesic activity (Corradini et al., 2001). Moreover, it prevented the inhibition of synaptosomial $\mathrm{K}^{+}$evoked $\left[{ }^{3} \mathrm{H}\right]-5-\mathrm{HT}$ release induced by agonists of NOP receptors, while it was inactive if administered alone (Calò et al., 2002). This last observation may explain the lack of influence of UFP-101 on paracetamol antinociception observed in the present study.

On the other hand, an antidepressant-like effect of UFP101 , possibly related to a potentiation of monoaminergic (in particular serotonergic) neurotransmission, has been reported (Gavioli et al., 2004). The only limited and nonsignificant (although dose-related) increase of paracetamol antinociception caused by UFP-101 observed in this study could mean a different relevance of the inhibitory actions of endogenous N/OFQ on serotonergic pathways related to pain modulation or to mood control.

In conclusion, this study shows an antagonistic effect of nociceptin/orphanin FQ and its analogue R-K on paracetamol-induced nociception with an action involving the NOP receptor. These results extend the knowledge on the antianalgesic role of nociceptin that has been until now largely (if not exclusively) related to opioid-induced analgesia.

Even if we cannot exclude other possible mechanisms of interaction between nociceptin and paracetamol, we suggest that serotonin might play a relevant role in this interaction since nociceptin/orphanin FQ and paracetamol have an opposite effect on serotonin levels at least in the cerebral cortex (Mela et al., 2004).

\section{Acknowledgements}

This work was supported in part by grants from MIUR (Cofin 2002). We wish to thank Dr. Calò and Dr. Guerrini for the gift of UFP-101.

\section{References}

Björkman, R., 1995. Central antinociceptive effects of non-steroidal antiinflammatory drugs and paracetamol. Acta Anaesthesiol. Scand. 39 (Suppl. 103), 7-43.

Calò, G., Rizzi, A., Rizzi, D., Bigoni, R., Guerrini, R., Marzola, G., Marti, M., Mc Donald, J., Morari, M., Lambert, D.G., Salvatori, S., Regoli, D., 2002. [Nphe ${ }^{1}, \mathrm{Arg}^{14}, \mathrm{Lys}^{15}$ ] nociceptin- $\mathrm{NH}_{2}$ a novel potent and selective antagonist of the nociceptin/orphanin FQ receptor. Br. J. Pharmacol. 136, 303-311.

Candeletti, S., Ferri, S., 2000. Effects of an antisense oligonucleotide to pronociceptin and long-term prevention of morphine actions by nociceptin. Peptides 21, 1119-1124.

Connor, M., Yeo, A., Anderson, G., 1996. The effect of nociceptin on $\mathrm{Ca}^{2+}$ channel current and intracellular $\mathrm{Ca}^{2+}$ in the SH-SY5Y human neuroblastoma cell line. Br. J. Pharmacol. 118, 205-207.

Corradini, L., Briscini, L., Ongini, E., Bertorelli, R., 2001. Putative $\mathrm{OP}_{4}$ antagonist, $\left[\mathrm{Nphe}^{1}\right.$ ]nociceptin $(1-13) \mathrm{NH}_{2}$, prevents the effects of nociceptin in neuropathic rats. Brain Res. 905 (1-2), 127-133. 
Courade, J.P., Chassaing, C., Bardin, L., Alloui, A., Eschalier, A., 2001. 5HT receptor subtypes involved in the spinal antinociceptive effect of acetaminophen in rats. Eur. J. Pharmacol. 432, 1-7.

Cox, B.M., Chavkin, C., Christie, M.J., Civelli, O., Evans, C., Hamon, M.D., Hoellt, V., Kieffer, B., Kitchen, I., McKnight, A.T., Meunier, J.C., Portoghese, P.S., 2000. The IUPHAR Compendium of Receptor Characterization and Classification. IUPHAR Media, Girdlestone, D., London.

Devine, D.P., Reinscheid, R.K., Monsma, F.J., Civelli, O., Akil, H., 1996. Rats rapidly develop tolerance to the locomotor-inhibiting effects of the novel neuropeptide orphanin FQ. Neurochem. Res. 21, 1387-1396.

Gavioli, E.C., Vaughan, C.W., Marzola, G., Guerrini, R., Mitchell, V.A., Zucchini, S., De Lima, T.C., Rae, G.A., Salvadori, S., Regoli, D., Calò, G., 2004. Antidepressant-like effects of the nociceptin/orphanin FQ receptor antagonist UFP-101: new evidence from rats and mice. Naunyn-Scmiedeberg's Arch. Pharmacol. 369, 547-553.

Harrison, L.M., Grandy, D.K., 2000. Opiate modulating properties of nociceptin/orphanin FQ. Peptides 21, 151-172.

Julius, D., 1995. Home for an orphan endorphin. Nature 76, 314-324.

Le Bars, D., Gozariu, M., Cadden, S.W., 2001. Animal models of nociception. Pharmacol. Rev. 53, 597-652.

Lufty, K., Sharza, A., Maidment, N.T., 1999. Tolerance develops to the inhibitory effect of orphanin FQ on morphine-induced antinociception in the rat. NeuroReport 10, 103-106.

Marti, M., Stocchi, S., Paganini, F., Mela, F., De Risi, C., Calò, G., Guerrini, R., Barnes, T.A., Lambert, D.G., Beani, L., Bianchi, C., Morari, M., 2003. Pharmacological profiles of presinaptic nociceptin/ orphanin FQ receptors modulating 5-hydroxytryptamine and noradrenaline release in the rat neocortex. Br. J. Pharmacol. 138, 91-98.

McCormack, N., 1994. Non-steroidal anti-inflammatory drugs and spinal nociceptive processing. Pain 59, 9-43.

Meis, S., 2003. Nociceptin/orphanin FQ: action within the brain. Neuroscientist 9, 158-168.

Mela, F., Marti, M., Ulazzi, L., Vaccai, E., Zucchini, S., Trapella, C., Salvatori, S., Beani, L., Bianchi, C., Morari, M., 2004. Pharmacological profile of nociceptin/orphanin FQ receptors regulating 5-hydroxytryptamine release in the mouse neocortex. Eur. J. Neurosci. 19, 1317-1324.

Meunier, J.C., Mollereau, C., Toll, I., Suaudeau, C., Rat, B., Guillemot, J.C., Ferrar, P., Monsarrat, B., Mazarguil, H., Vassart, G., Parmentier, M., Costentin, J., 1995. Isolation and structure of the endogenous agonist of the opioid receptor-like ORL1 receptor. Nature 337, 532-535.
Mogil, Y.S., Pasternak, G.W., 2001. The molecular and behavioural pharmacology of orphanin $\mathrm{FQ}$ /nociceptin peptide and receptor family. Pharmacol. Rev. 45, 381-415.

Mogil, J.S., Griesel, J.E., Reinscheid, R.K., Civelli, O., Belknap, J.K., Grandy, D.K., 1996. Orphanin FQ is a functional anti opioid peptide. Neuroscience 15, 333-337.

Paxinos, G., Watson, C., 1997. The Rat Brain Stereotaxic Coordinates. Academic Press, New York.

Pellissier, T., Alloui, A., Paeile, C., Eschalier, E., 1995. Evidence on central antinociceptive effect of paracetamol involving spinal $5-\mathrm{HT}_{3}$ receptors. NeuroReport 6, 983-993.

Pelissier, T., Alloui, A., Caussade, F., Dubray, A., Cloarec, A., Lavarenne, J., Eschalier, A., 1996. Paracetamol exerts a spinal antinociceptive effect involving an indirect interaction with 5-hydroxytryptamine 3 receptors: in vivo and in vitro evidence. J. Pharmacol. Exp. Ther. $287,8-14$.

Pini, L.A., Sandrini, M., Vitale, G., 1996. The antinociceptive action of paracetamol is associated with changes in the serotonergic system in the rat brain. Eur. J. Pharmacol. 308, 31-40.

Pini, L.A., Vitale, G., Ottani, A., Sandrini, M., 1997. Naloxone-reversible antinociception by paracetamol in the rat. J. Pharmacol. Exp. Ther. 280, 934-940.

Rizzi, D., Rizzi, A., Bigoni, R., Camarda, V., Marzola, G., Guerrini, R., De Risi, C., Regoli, D., Calò, G., 2002. $\left[\operatorname{Arg}^{14}\right.$, Lys $\left.{ }^{15}\right] \mathrm{NC}$, a high potent agonist of nociceptin/orphanin FQ receptor: in vitro and in vivo studies. J. Pharmacol. Exp. Ther. 300, 57-63.

Sbrenna, S., Marti, M., Morari, M., Calò, G., Guerrini, R., Beani, L., Bianchi, C., 2000. Modulation of 5-hydroxytryptamine efflux from rat cortical synaptosomes by opioids and nociceptin. Br. J. Pharmacol. 130, $425-433$.

Schlicker, E., Morari, M., 2000. Nociceptin/orphanin/FQ and neurotransmitter release in central nervous system. Peptides 21, 1023-1029.

Vaugham, C.W., Christie, M.J., 1996. Increase by the ORL1 receptor (opioid-like1) ligand, nociceptin, of inwardly rectifying $\mathrm{K}$ conductance in dorsal raphe nucleus neurones. Br. J. Pharmacol. 117, 1609-1611.

Wang, J.-L., Zhu, C.B., Cao, X.D., Wu, G.C., 1999. Distinct effect of intracerebroventricular and intrathecal injection of noceptin/orphanin FQ in the rat formalin test. Regul. Pept. 79, 159-163.

Zhu, C.B., Zhang, X.L., Cao, X.D., Wu, G.C., Li, M.Y., Cui, D.F., Qi, Z.W., 1998. Antagonistic effect of orphanin FQ on opioid analgesia in rat. Acta Pharmacol. Sin. 19, 10-14. 